\title{
APLIKASI PENENTUAN RUTE TERPENDEK UNTUK BAGIAN PEMASARAN PRODUK ROTI SURYA DENGAN METODE BEST FIRST SEARCH
}

\author{
Aldisen Juniansyah, Mesterjon \\ Program Studi Teknik Informatika Fakultas Ilmu Komputer Universitas Dehasen Bengkulu \\ Jl. Meranti Raya No. 32 Kota Bengkulu 38228 Telp. (0736) 22027, 26957 Fax. (0736) 341139
}

\section{ABSTRACT}

Policy decide journey route trajectory sequence part of this is marketing very is needed, because closely related with expense use of required oil fuel each time do marketing to marketing dot. Referred as closely related with expense of use of oil fuel perhaps progressively far marketing trajectory to be passed by to the same purpose, hence will be ever greater also expense which must by company. Pursuant to result of test-drive which have been conducted, application Determination short band route to part of surya bread product marketing with Best search first method, owning interesting appearance and way of using simple, easy to understanding.

Keyword: Application, Shortest Route, Best First Search

\section{INTISARI}

Kebijakan memutuskan urutan lintasan rute perjalanan bagian pemasaran ini sangat diperlukan, karena berhubungan erat dengan biaya penggunaan bahan bakar minyak yang dibutuhkan setiap kali melakukan pemasaran ke titik-titik pemasaran. Disebut berhubungan erat dengan biaya penggunaan bahan bakar minyak tentunya semakin jauh lintasan pemasaran yang akan dilalui dengan tujuan yang sama, maka akan semakin besar pula biaya yang harus dikeluarkan oleh perusahaan. Berdasarkan hasil uji coba yang telah dilakukan, Aplikasi penentuan rute jalur terpendek untuk bagian pemasaran produk roti surya dengan metode Best first search, memiliki tampilan yang menarik dan cara menggunakan yang sederhana, mudah di mengerti.

Kata Kunci: Aplikasi, Rute Jalur Terpendek, Best First Search

\section{PENDAHULUAN}

Komputer merupakan perangkat keras yang sampai saat ini keberadaannya tidak dapat lagi dielakkan, karena hampir pada semua aktifitas manusia secara sadar atau tidak telah terlibat, terkait dan tergantung pada komputer. Baik ketergantungan dalam informasi, pengolahan data, hiburan maupun komputer sebagai alat pengolah data bagi seorang pimpinan dalam menentukan kebijakan yang telah didasarkan pada hasil pengolahan data yang menggunakan komputer sebagai alat olah data.

Sebagai peralatan canggih yang memiliki banyak kemampuan, komputer sangat diperlukan dalam melakukan pengolahan data agar didapatkan hasil yang baik dan optimal sesuai dengan kebutuhan. Kemampuan kerja komputer tersebut tentunya tidak terlepas dari perangkat lunak yang sesuai dan operator yang menjalankan. Sebagai contoh, seorang manajer dalam menentukan rute perjalanan bagi bagian pemasaran produk sangat memerlukan bantuan komputer dalam melakukan pengolahan data jalur-jalur yang akan dilalui. Karena dengan menggunakan perhitungan manual, maka dapat dibayangkan memerlukan waktu yang sangat lama.

Kebijakan memutuskan urutan lintasan rute perjalanan bagian pemasaran ini sangat diperlukan, karena berhubungan erat dengan biaya penggunaan bahan bakar minyak yang dibutuhkan setiap kali melakukan pemasaran ke titik-titik pemasaran. Disebut berhubungan erat dengan biaya penggunaan bahan bakar minyak (BBM) tentunya semakin jauh lintasan pemasaran yang akan dilalui dengan tujuan yang sama, maka akan semakin besar pula biaya yang harus dikeluarkan oleh perusahaan.

Teknologi informasi merupakan bidang ilmu yang mempelajari penggalian data, fakta dan berbagai informasi seluas-luasnya baik berupa angka, teks, gambar, sinyal analog maupun digital. Selanjutnya berbagai sumber data tersebut dikelompokkan, dimodifikasi, ditransfomasi dan diolah ke dalam bentuk lain untuk dijadikan data baru, fakta baru, informasi baru yang dibutuhkan oleh pengguna yang semuanya dapat disebut sebagai informasi.

\section{TINJAUAN PUSTAKA}

\section{A) Pengertian Aplikasi}

Anonim (2013:1), perangkat lunak aplikasi (bahasa Inggris: application software) adalah suatu subkelas perangkat lunak komputer yang memanfaatkan kemampuan komputer langsung untuk melakukan suatu tugas yang diinginkan pengguna. Biasanya dibandingkan dengan perangkat lunak sistem yang mengintegrasikan berbagai kemampuan komputer, tapi tidak secara langsung menerapkan 
kemampuan tersebut untuk mengerjakan suatu tugas yang menguntungkan pengguna. Contoh utama perangkat lunak aplikasi adalah pengolah kata, lembar kerja, dan pemutar media.

Beberapa aplikasi yang digabung bersama menjadi suatu paket kadang disebut sebagai suatu paket atau suite aplikasi (application suite). Contohnya adalah Microsoft Office dan OpenOffice.org, yang menggabungkan suatu aplikasi pengolah kata, lembar kerja, serta beberapa aplikasi lainnya. Aplikasi-aplikasi dalam suatu paket biasanya memiliki antarmuka pengguna yang memiliki kesamaan sehingga memudahkan pengguna untuk mempelajari dan menggunakan tiap aplikasi. Sering kali, mereka memiliki kemampuan untuk saling berinteraksi satu sama lain sehingga menguntungkan pengguna. Contohnya, suatu lembar kerja dapat dibenamkan dalam suatu dokumen pengolah kata walaupun dibuat pada aplikasi lembar kerja yang terpisah.

\section{B) Algoritma Pencarian}

Pencarian adalah suatu proses mencari solusi dari suatu permasalahan melalui sekumpulan kemungkinan ruang keadaan (state space). Ruang keadaan merupakan suatu ruang yang berisi semua keadaan yang mungkin. Dalam ilmu komputer, sebuah algoritma pencarian dijelaskan secara luas merupakan algoritma yang menerima masukan berupa sebuah masalah dan menghasilkan sebuah solusi untuk masalah tersebut, yang biasanya didapat dari evaluasi beberapa kemungkinan solusi. Himpunan semua kemungkinan solusi dari sebuah masalah disebut ruang pencarian. Algortima pencarian brute-force atau pencarian uninformed menggunakan metode yang sederhana dan sangat intuitif pada ruang pencarian, sedangkan algoritma pencarian informed menggunakan heuristik untuk menerapkan pengetahuan tentang struktur dari ruang pencarian untuk berusaha mengurangi banyaknya waktu yang dipakai dalam pencarian (Nilson. J, 1998).

\section{C) Pengertian Jalur Terpendek}

Menurut Mudi Arsa (2010), untuk menemukan lintasan terpendek antara dua atau beberapa simpul lebih yang berhubungan. Persoalan mencari lintasan terpendek di dalam graf merupakan salah satu persoalan optimasi. Persoalan ini biasanya direpresentasikan dalam bentuk graf. Graf yang digunakan dalam pencarian lintasan terpendek atau shortest path adalah graf berbobot (weighted graph), yaitu graf yang setiap sisinya diberikan suatu nilai atau bobot. Bobot pada sisi graf dapat menyatakan jarak antar kota, waktu pengiriman pesan, ongkos pembangunan, dan sebagainya.

\section{D) Pengertian Algoritma Best First Search}

Best-First Search merupakan sebuah metode yang membangkitkan simpul dari simpul sebelumnya. Best-first search memilih simpul baru yang memiliki biaya terkecil diantara semua leaf nodes (simpulsimpul pada level terdalam) yang pernah dibangkitkan. Penentuan simpul terbaik dilakukan dengan menggunakan sebuah fungsi yang disebut fungsi evaluasi $f(n)$. fungsi evaluasi best-first search dapat berupa biaya perkiraan dari suatu simpul menuju ke goal atau gabungan antara biaya sebenarnya dan biaya perkiraan tersebut.

\section{E) Sistem Komputer}

Menurut Mulyono (2008:1) Sistem Komputer adalah alat elektronik yang mampu melakukan beberapa tugas, yaitu menerima input, memproses input sesuai dengan instruksi yang diberikan, menyimpan perintah dan hasil pengolahannya, serta menyediakan output dalam bentuk informasi.

1) Bahasa Pemrograman: Merupakan perangkat lunak yang bertugas mengkorversikan arsitektur dan algoritma yang dirancang manusia kedalam format yang dijalankan komputer

2) Sistem Operasi: Sistem operasi merupakan sistem software yang berfungsi untuk mengatur kerja komputer secara mendasar seperti mengatur media input - proses - output, mengatur penjadwalan processor.

3) Program Paket (Package Program): Paket Program merupakan program yang dikerjakan dalam salah satu bahasa yang disiapkan untuk suatu bidang, Adapun macam-macam program paket/program aplikasi (Wordstar, Microsoft Word, Excel, Autocad dan lain sebagainya).

4) Utility Program: Utility Program yaitu programprogram yang telah jadi untuk menunjang system operasi dan biasanya diberikan oleh pabrik, misalnya sortir, Format, copy, dan lain sebagainya.

\section{F) Perangkat Keras (Hardware)}

Perangkat keras adalah peralatan sistem komputer yang secara fisik dapat disentuh, hal itu sesuai dengan ungkapan yang disampaikan oleh Mulyono (2008:3) tentang pengertian perangkat keras, yakni perangkat keras adalah peralatan sistem komputer yang secara fisik dapat dilihat/dijamah. Komponen utama 
perangkat keras sistem komputer adalah sebagai berikut :

1) Unit masukan (input), adalah perangkat keras yang berfungsi sebagai alat untuk memasukkan data atau perintah ke dalam komputer. Unit masukan terdiri atas alat masukan langsung dan alat masukan tidak langsung. Contohnya adalah keyboard, mouse, scanner, bar-code reader, disk drive, touch screen, light pen dan sebagainya.

2) Unit pusat pengolah (CPU), merupakan otak sistem komputer sebagai tempat untuk mengolah instruksi program yang pada komputer ukuran mikro disebut sebagai micro processor.

3) Unit keluaran (output), adalah perangkat keras yang berfungsi untuk menampilkan/mencetak keluaran sebagai hasil pengolahan data. Unit keluaran ini berupa hard copy device, soft copy device dan drive device. Contohnya printer, plotter, monitor, speaker, LCD monitor dan lain-lain.

4) Media penyimpan (memory), digunakan untuk menyimpan data, informasi dan program pengolah. Memori dibedakan menjadi dua, yaitu memori internal dan memori eksternal. Memori internal berupa RAM (Random Access Memory) yang berfungsi untuk menyimpan program yang diolah sementara waktu dan ROM (Read Only Memory) yaitu memori yang hanya bisa dibaca dan berguna sebagai penyedia informasi pada saat komputer pertama kali dinyalakan karena komputer membaca catatan BIOS yang disimpan di dalam ROM.

\section{G) Perangkat Lunak (Software)}

Perangkat lunak komputer merupakan serangkaian instruksi dengan aturan tertentu yang mengatur operasi perangkat keras, Perangkat lunak terdiri atas 3 kelompok, yakni :

1) Sistem Operasi (Operating System), adalah perangkat lunak yang digunakan untuk mengendalikan resources selama proses berlangsung. Fungsi sistem operasi adalah mengalokasikan memori dan pekerjaan dan penjadwalan pekerjaan. Contoh : DOS, Unix, Novell, OS/2, Windows.

2) Bahasa Pemrograman (Programming Language), adalah merupakan perangkat lunak yang digunakan untuk pengembangan program aplikasi. Level/generasi bahasa pemrograman komputer dikenal dengan $4 \mathrm{GL}$, yaitu : bahasa mesin (machine language), bahasa rakitan (assembly language), bahasa pemrograman (programming language) dan aplikasi (application).
3) Bahasa Query (Query Language), adalah merupakan perangkat lunak bahasa tingkat sangat tinggi yang dapat digunakan untuk menampilkan informasi-informasi yang diinginkan hanya dengan menuliskan sedikit perintah, contoh SQL (Structure Query Language)

4) Aplikasi (Application), adalah merupakan perangkat lunak yang dukembangkan untuk digunakan pada aplikasi tertentu.

\section{H) Perangkat Cerdas atau Manusia (Brainware)}

Perangkat cerdas atau manusia adalah merupakan personal yang terlibat dalam sistem komputer, yaitu operator bertugas sebagai ujung tombak diawal yang dapat berlaku sebagai tenaga untuk menjalankan program, programmer berlaku sebagai orang yang merancang program.

\section{METODOLOGI PENELITIAN}

\section{A) Metode Penelitian}

Dalam melakukan penelitian ini, peneliti menggunakan metode pengembangan sistem yang sesuai dengan pembahasan atau topik permasalahan yang dibahas oleh peneliti. Pengembangan sistem merupakan salah satu metode yang dibuat dalam bentuk modifikasi sistem yang sudah ada ataupun pengembangan sistem yang belum ada atau baru.

Prosedur penelitian yang akan dilakukan yaitu untuk mengetahui hubungan sebab akibat dua variable atau lebih dengan mengendalikan pengaruh variable yang lain yaitu menganalisa kebutuhan akan data, mengembangkan sistem, implementasi sistem, dan pemeliharaan sistem.

\section{B) Metode Perancangan Sistem \\ 1) Analisa Sistem Aktual}

Dalam menjalankan usahanya, sistem yang selama ini digunakan oleh Roti Surya Bengkulu adalah bagian pemasaran langsung bergerak sesuai dengan keinginan dari pengemudinya. Sehingga sangat besar kemungkinan akan terjadi pengulangan lintasan yang telah dilalui. Hal ini tentunya selain tidak hemat, juga akan menimbulkan kelelahan dan rendahnya hasil pemasaran.

Pola pengelolaan usaha seperti itu tentunya sangat banyak faktor kerugian yang akan dihadapi daripada kebaikan yang dirasakan oleh pemilik. Karena secara kumulatif, permasalahan manajemen konvensional ini nantinya akan banyak menimbulkan kesulitan selama pelaksanaannya. Adapun beberapa kesulitan dan kelemahan yang akan dihadapai tersebut dapat dijelaskan sebagai berikut : 
a) Rendahnya keamanan data yang tersimpan di dalam buku penjualan maupun buku kegiatan harian.

b) Rendahnya kerapihan dan susunan rekaman data yang ada.

c) Tidak seragamnya bentuk keluaran yang terbuat. Sulitnya menyusun produktifitas usaha.

\section{2) Analisa Sistem Baru}

Untuk menanggulangi berbagai kelemahan dari sistem lama yang selama digunakan oleh pihak manajemen Roti Surya Bengkulu, maka perlu adanya suatu cara yang dapat membantu perusahaan khususnya bagian pemasaran untuk memilih jalur terpendek agar dapat menghemat biaya, sehingga akan mempercepat sampainya ke titik tujuan. Dengan demikian akan dapat menghemat biaya pemasaran dan sekaligus menjamin bagi konsumen akan ketepatan waktu sampainya bagian pemasaran.

\section{a) Diagram Alir Data (Data Flow Diagram)}

Diagram alir data dalam penelitian ini disajikan dalam dua bentuk, yaitu diagram konteks dan diagram alir data level 1. Kedua diagram tersebut masing-masing disajikan pada Gambar 1 dan 2.

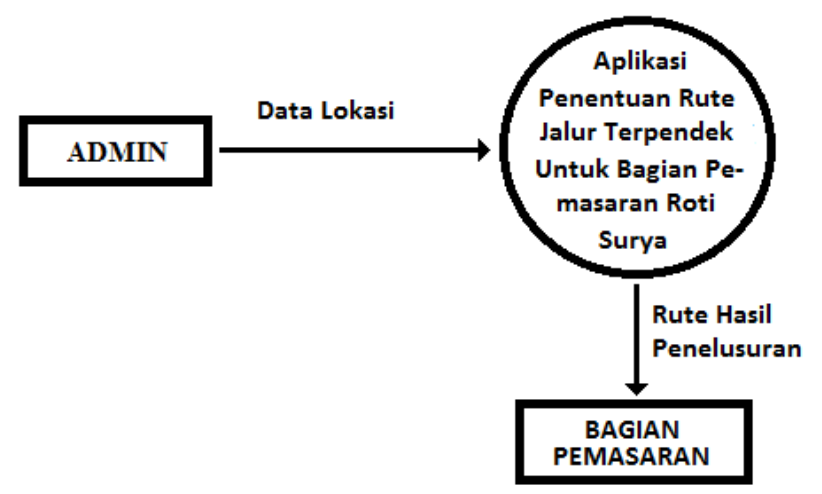

Gambar 1. Diagram Konteks

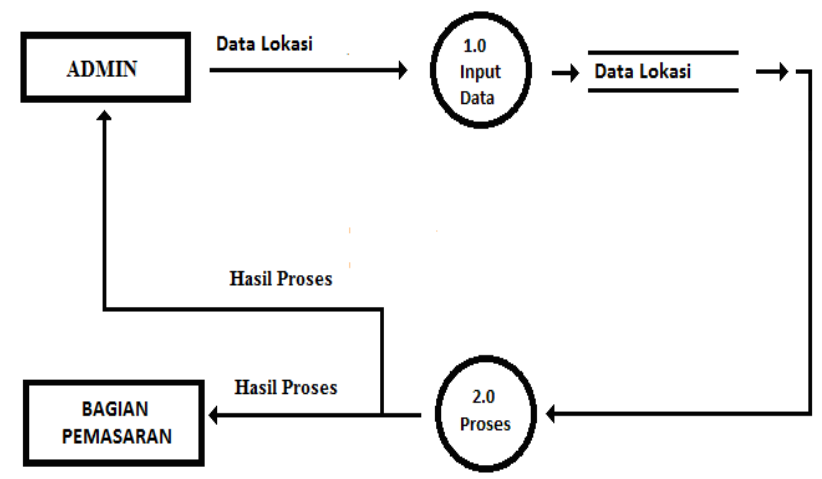

Gambar 2. Diagram Alir Data Level 0

b) Rancangan File

\section{File Data Admin}

Nama Tabel : Admin

Primary Key : -

Foreign Key : -

Tabel 1. Tabel Data Admin

\begin{tabular}{|l|l|l|l|l|}
\hline No. & Nama Field & Tipe & Ukuran & Keterangan \\
\hline 1. & Password & Text & 5 & Password \\
\hline 2. & NmAdmin & Text & 25 & Nama Admin. \\
\hline
\end{tabular}

File Data Lokasi

Nama Tabel : Lokasi

Primary Key : KdLokasi

Foreign Key : -

Tabel 2. Tabel Data Lokasi

\begin{tabular}{|l|l|l|l|l|}
\hline No. & Nama Field & Tipe & Ukuran & Keterangan \\
\hline 1. & KdLokasi & Text & 2 & Kode Lokasi \\
\hline 2. & NmLokasi & Text & 35 & Nama Lokasi \\
\hline 3. & Jarak & Single & - & Jarak Lokasi \\
\hline
\end{tabular}

c) Rancangan Struktur Menu

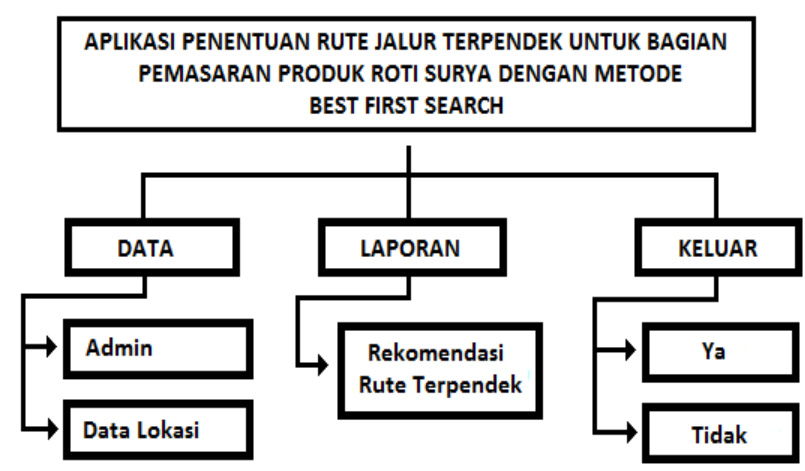

Gambar 3. Tampilan Struktur Menu

d) Rancangan Menu Utama

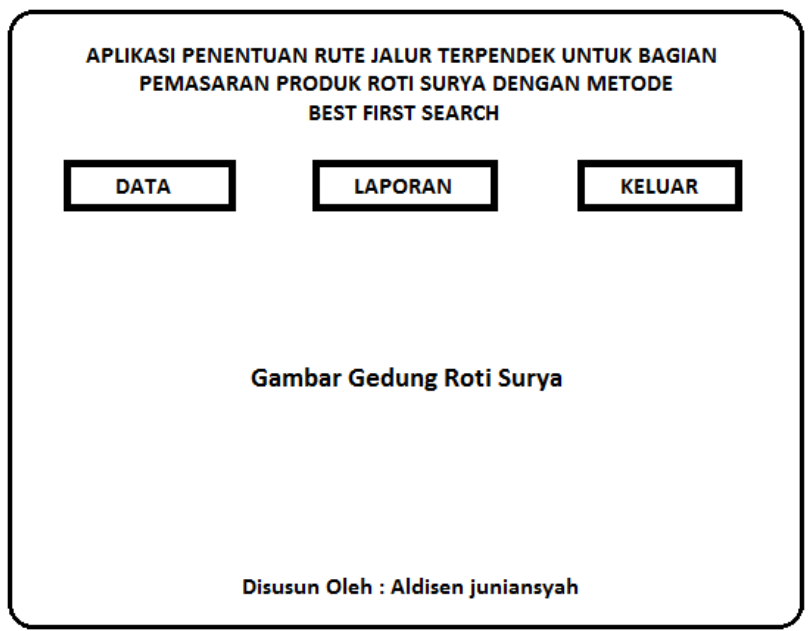

Gambar 4. Tampilan Menu Utama 
e) Rancangan Sub-Menu Data

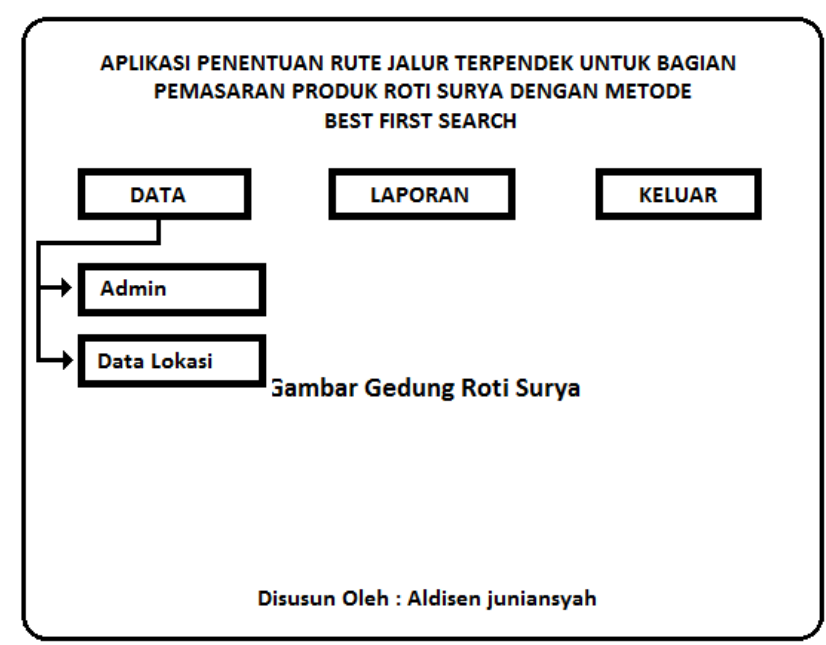

Gambar 5. Tampilan Sub-Menu Data

f) Rancangan Sub-Menu Laporan

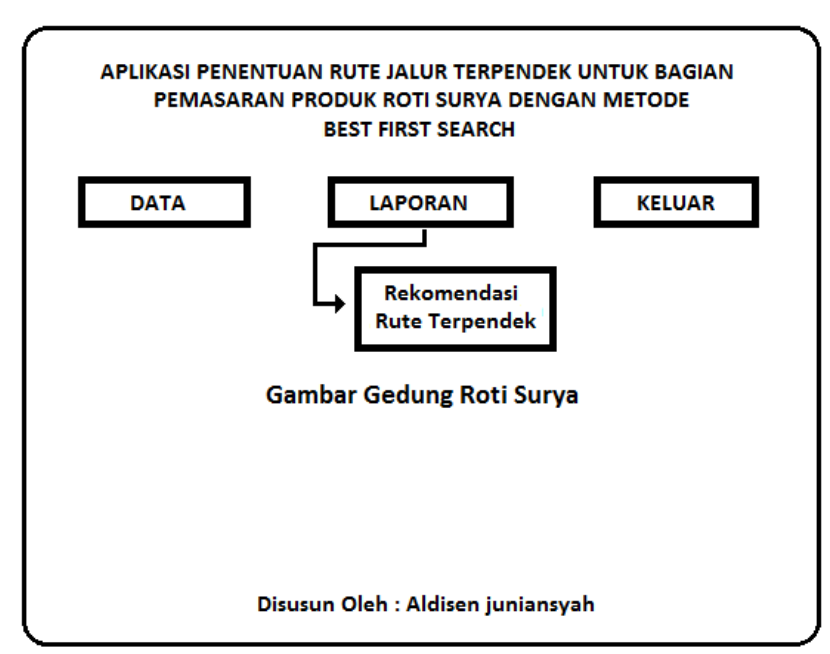

Gambar 6. Tampilan Sub-Menu Laporan

g) Rancangan Sub-Menu Keluar

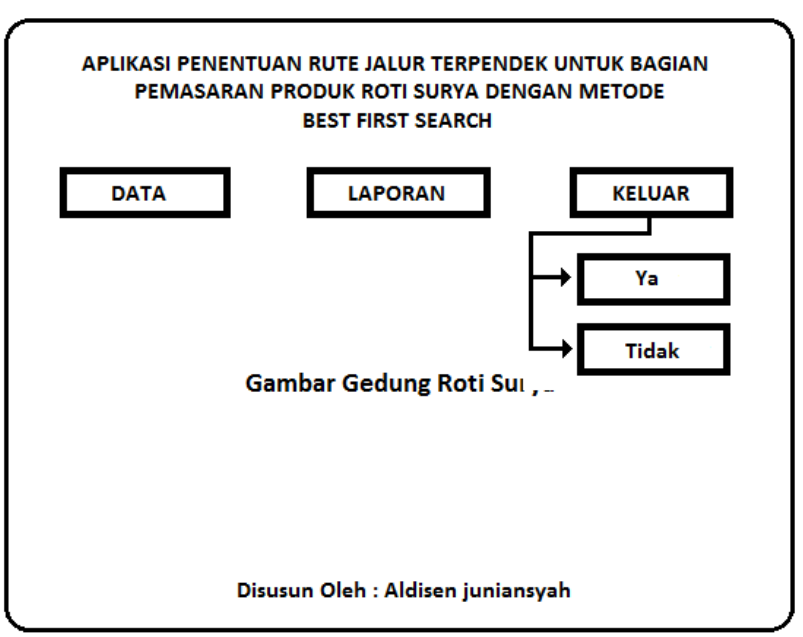

Gambar 7. Tampilan Sub-Menu Keluar h) Rancangan Input Data

Rancangan Input Data Admin

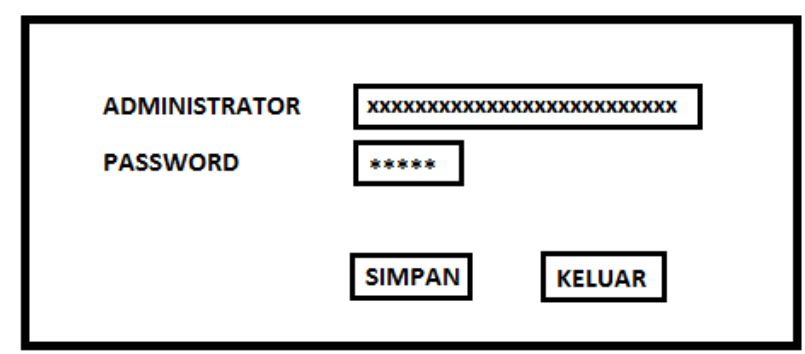

Gambar 8. Input Data Admin

\section{Rancangan Input Data Lokasi}

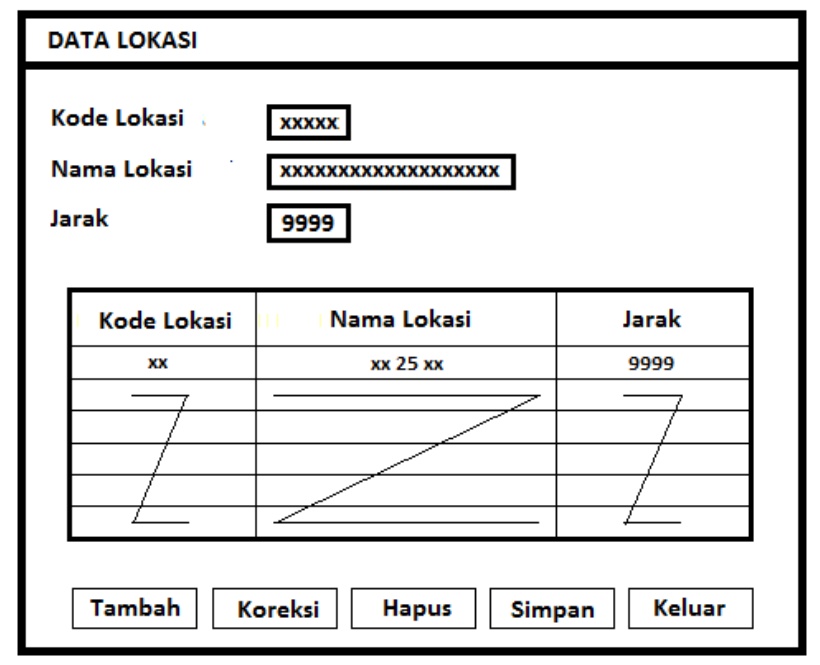

Gambar 9. Input Data Lokasi

\section{Rancangan Proses Penelusuran Jalur}

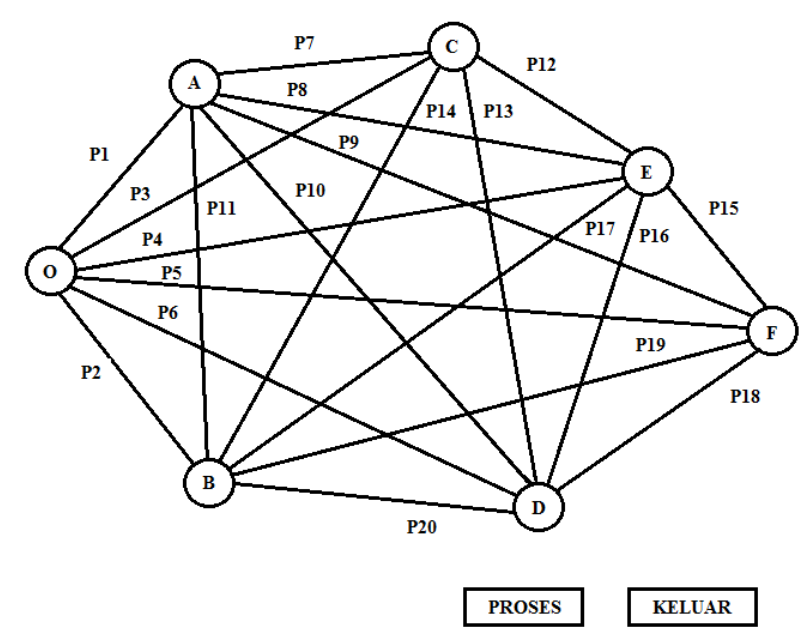

Gambar 10. Tampilan Proses Penelusuran Jalur 


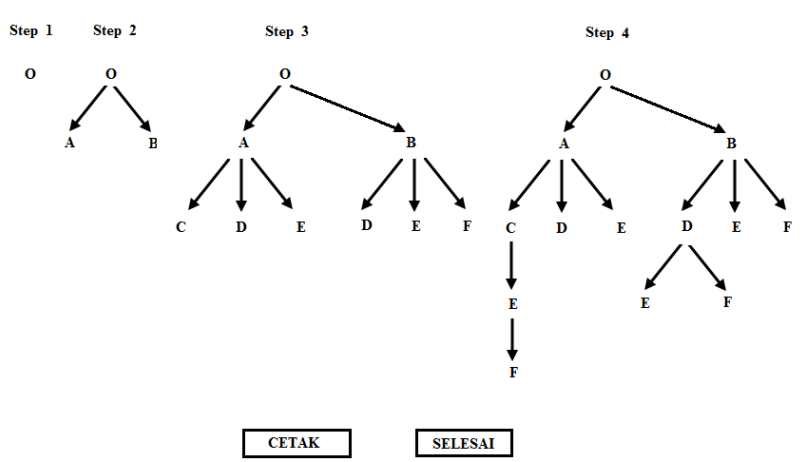

Gambar 11. Tampilan Proses Penelusuran Dengan Best First Search

\section{C) Rancangan Pengujian}

Rancangan pengujian yang akan peneliti lakukan rencananya akan dilaksanakan dalam dua tahap, yakni tahap pengujian black-box yaitu pelaksanaan pengujian yang dilakukan dengan memfokuskan pada algoritma program. Pengujian dengan metode black box ini bertujuan untuk mendapatkan kesalahan karena fungsi-fungsi, prosedur-prosedur dan variabel-variabel yang hilang (fungsi, prosedur, variabel yang seharusnya ada).

Tahap berikutnya adalah pengujian dengan metode White Box, yakni pengujian yang memfokuskan pada keperluan fungsional dari software. Karena itu pengujian dengan metode white box memungkinkan pengembang software untuk menelaah perfoma, interface dan integritas dari program. Dengan demikian pengujian dengan metode white box ini bertujuan untuk mendapatkan kesalahan karena rangkaian class dan module, serta fungsifungsi, prosedur-prosedur dan variabel-variabel yang terangkai.

\section{PEMBAHASAN}

\section{A. Hasil dan Pembahasan Program}

Program pencarian rute terpendek pada Perusahaan Roti Surya ini merupakan hasil dari rancangan system yang telah diajukan sebelumnya. Program ini dapat diaktifkan melalui Run maupun Explore karena file tersebut telah berbentuk sebagai file Aplikasi. Sedangkan source programnya baru dapat diaktifkan apabila pada komputer telah terpasang MicroSoft Visual Basic 60. Adapun apabila program tersebut diaktifkan, maka pertama kali pada layar akan terlihat tampilan program seperti terlihat pada Gambar 12.

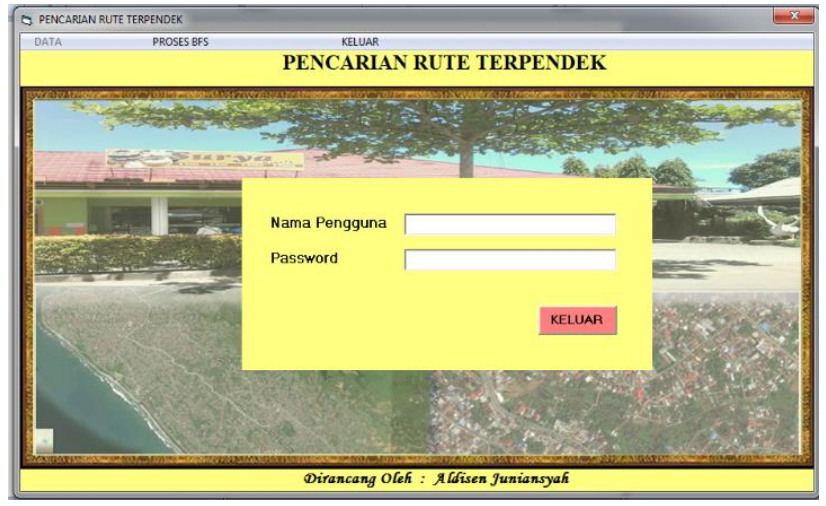

Gambar 12. Tampilan Menu Awal

Berdasarkan Gambar 12 dapat diamati bahwa, program tersebut melakukan pembatasan penggunaan dengan cara meminta nama pengguna dan password. Hal itu dimaksudkan agar program tersebut tidak bebas dibuka oleh orang yang tidak memiliki akun yang benar.

Setelah nama pengguna dan password yang diisikan benar, maka program kemudian akan menampilkan tombol Log In guna memberikan informasi bagi pengguna untuk meng-klik tombol Log In dengan tampilan seperti pada Gambar 13.

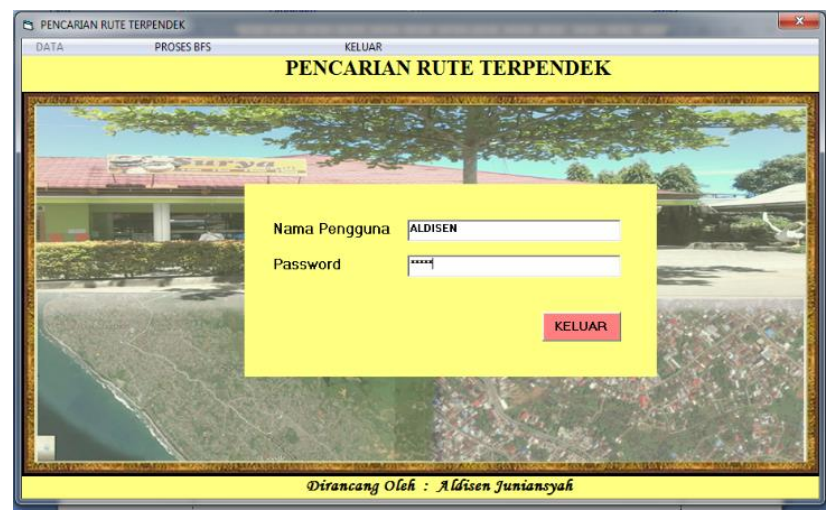

Gambar 13. Tampilan Log In

Sebagaimana lazimnya form Log In, apabila pengisian nama pengguna serta passwordnya tidak benar, maka program akan menolak melanjutkan proses sampai pengisian kombinasi nama pengguna dan passwordnya benar. Sedangkan apabila kombinasi nama pengguna serta password yang diisikan sudah benar, program selanjutnya akan menggulung dialog-box Log In yang selanjutnya memberikan tampilan seperti Gambar 14 berikut dengan diikuti aktifnya pilihan: Data dan Proses BFS. 


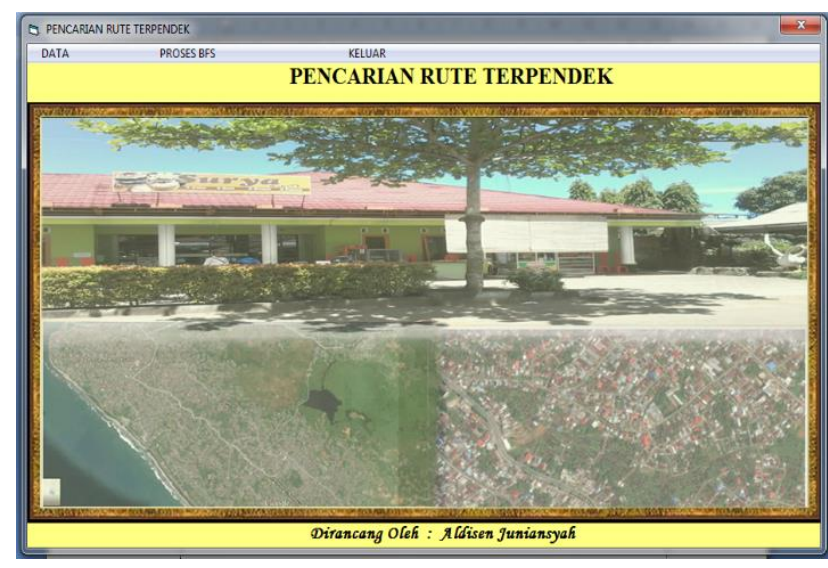

Gambar 14. Tampilan Sub Menu Utama

Berdasarkan pada tampilan Gambar 14, dapat dipahami bahwa menu utama tersebut memiliki tiga macam menu, yakni Data, Laporan dan Keluar. Menu Data disediakan untuk melakukan pengelolaan terhadap data-data dasar yang akan digunakan. Menu Laporan disediakan untuk melayani pembuatan laporan, sedangkan menu Keluar disediakan apabila pengguna akan keluar dari program.

Berikut ini berturut-turut akan diuraikan masingmasing menu yang tersedia beserta tampilan layarnya seperti terlihat pada Gambar 15, Gambar 16 dan Gambar 17 dari menu utama program.

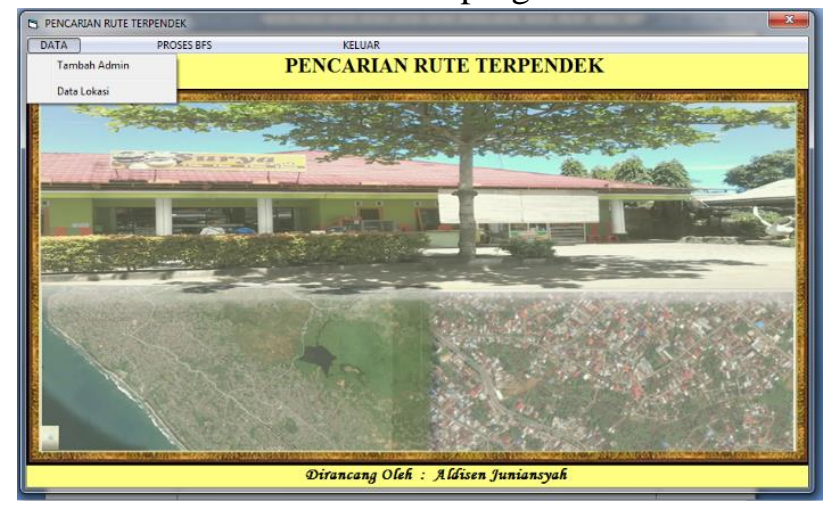

Gambar 15. Tampilan Sub Menu Data

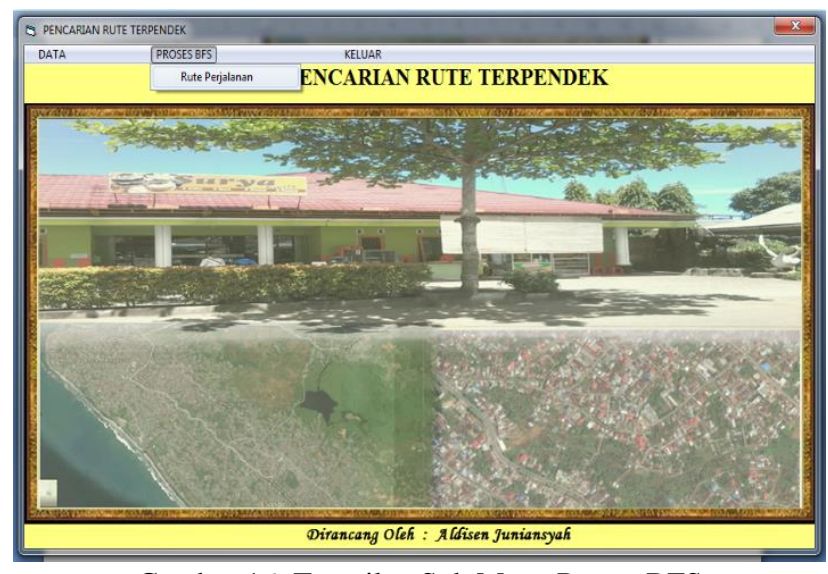

Gambar 16. Tampilan Sub Menu Proses BFS

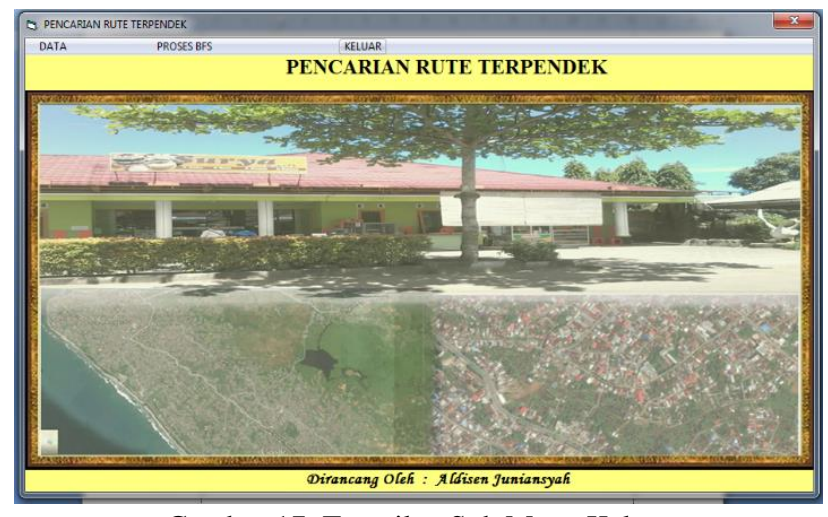

Gambar 17. Tampilan Sub Menu Keluar

Seperti telah dijelaskan pada tersebut, dimana sub menu Data terdiri dari beberapa pilihan. Berikut ini adalah penjelasan dan manfaat dari masing-masing pilihan yang tersedia.

a. Sub Menu Data

Sesuai dengan namanya, sub menu Data disediakan untuk melayani pengguna dalam hal pengelolaan terhadap data-data yang ada serta penambahan data penggunanya.

\section{Tambah Admin}

Pilihan Tambah Admin pada sub menu Data ini dimaksudkan apabila diinginkan oleh pemilik untuk menambah orang yang akan diizinkan menggunakan program.

Adapun tampilan dari form Tambah Admin tersebut dapat dilihat seperti pada Gambar 18.

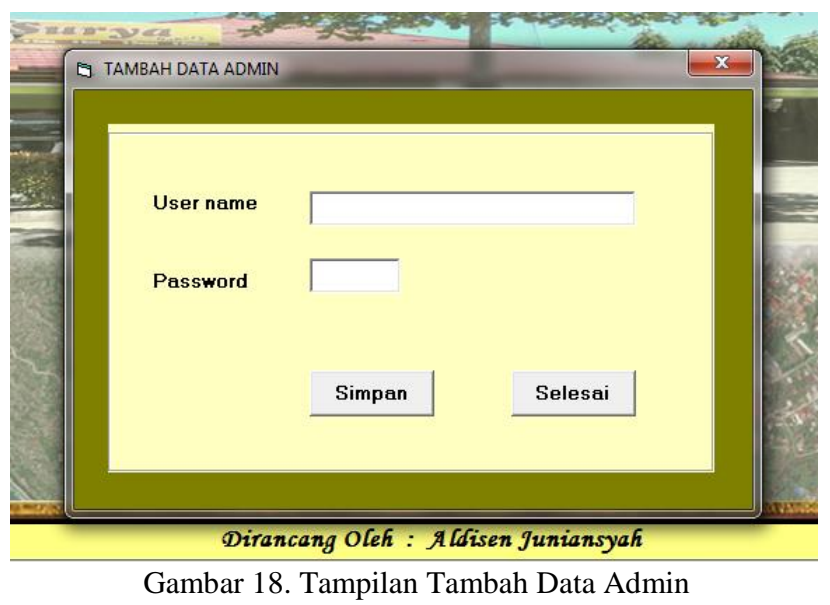

Berdasarkan tampilan pada Gambar 18 di atas, dapat dijelaskan bahwa formulir tersebut berfungsi sebagai tatap muka (interface) guna melakukan penambahan data admin.

\section{Data Lokasi}

Data Lokasi disediakan guna untuk menginputkan atau menghapus lokasi yang akan dituju. Untuk menampilkan Formulir Data Produk, dari Menu 
Utama diklik Data dan dilanjutkan dengan meng-klik Data Lokasi, maka pada layar akan terlihat tampilan seperti Gambar 19.

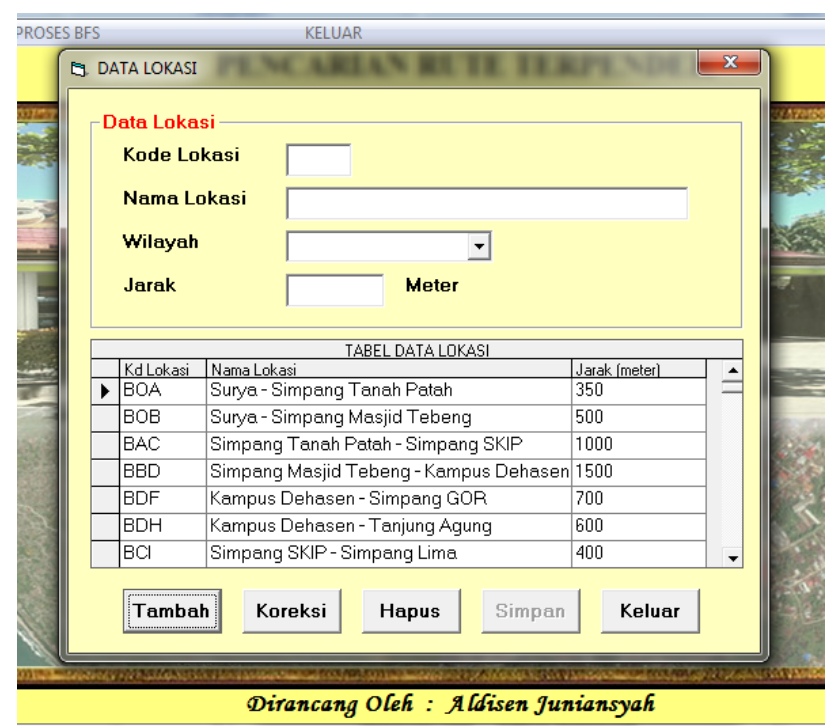

Gambar 19. Tampilan Form Data Lokasi

\section{b. Sub Menu Proses}

Menu Proses disediakan guna untuk memproses data-data yang telah diinputkan dengan menggunakan metode Best First Seacrh. Untuk menampilkan Proses dan hasil tersebut, dari Menu Utama diklik Data dan dilanjutkan dengan meng-klik Proses, maka pada layar akan terlihat tampilan Gambar 20, 21, 22 dan 23.

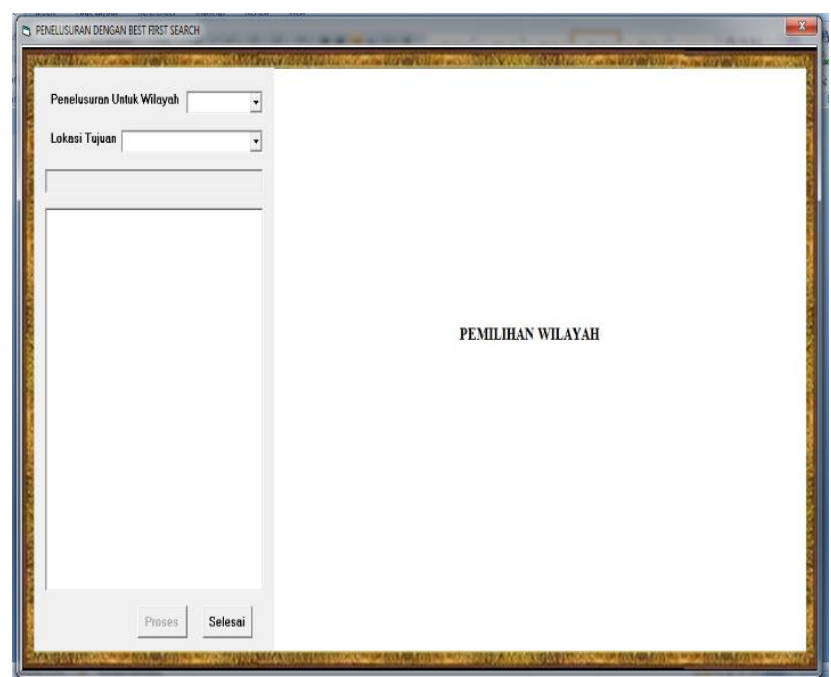

Gambar 20. Menu Proses Pencarian Rute

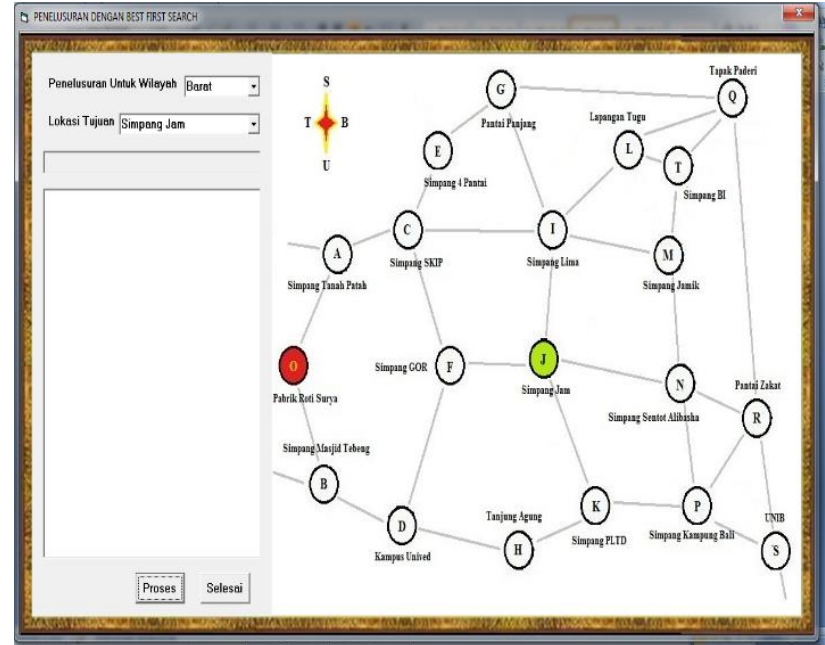

Gambar 21. Menu Proses Pencarian Rute Untuk Wilayah Barat

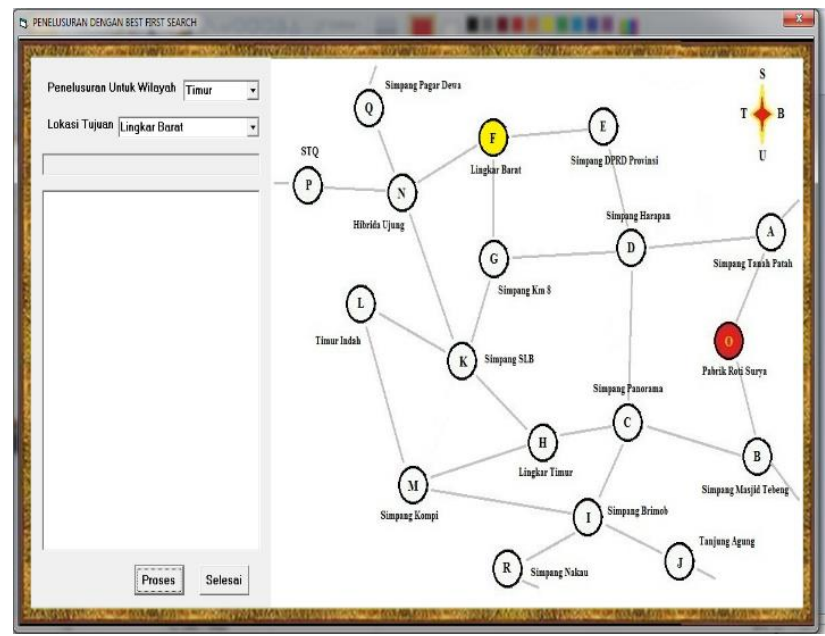

Gambar 22. Menu Proses Pencarian Rute Untuk Wilayah Timur

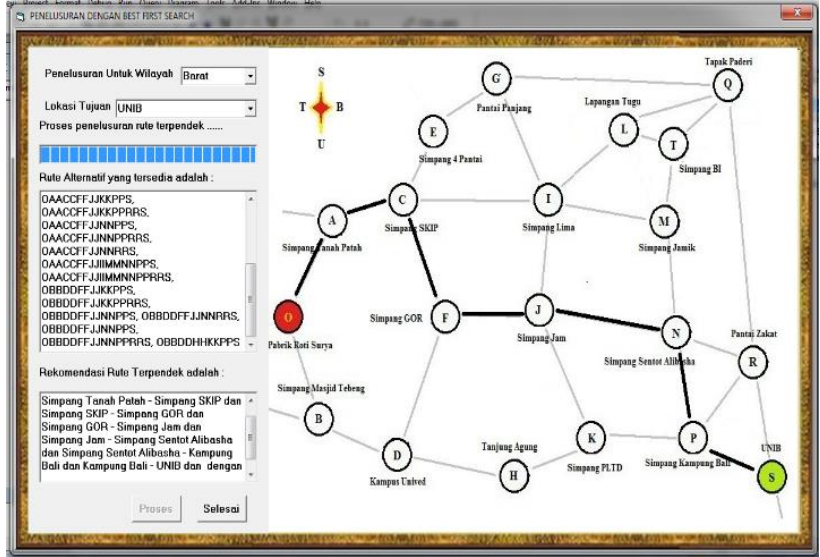

Gambar 23. Hasil Pencarian Rute Dengan Metode BFS

c. Sub Menu Keluar

Menu ini merupakan menu penutup aplikasi. Seperti terlihat pada Gambar 24. 


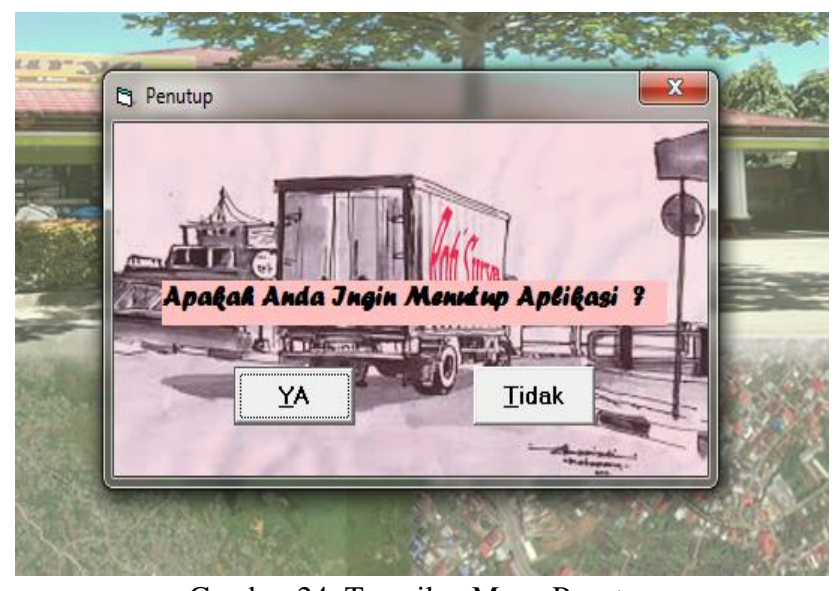

Gambar 24. Tampilan Menu Penutup

\section{A) Pengujian Sistem}

Pengujian aplikasi pencarian rute jalur terpendek ini dilakukan di Perusahaan Roti Surya Bengkulu dengan menggunakan komputer dan kuisioner (terlampir). Berdasarkan hasil pengujian system yang dilakukan antara sistem lama dan sistem baru, maka didapatkan hasil seperti pada Tabel 3.

Tabel 3. Hasil Pengujian Sistem Lama dan Sistem Baru

\begin{tabular}{|c|c|c|}
\hline Jenis Penelitian & Sistem Lama & Sistem Baru \\
\hline $\begin{array}{l}\text { Pencarian Rute } \\
\text { Jalur } \\
\text { Terpendek } \\
\text { Dengan } \\
\text { Menggunakan } \\
\text { Metode Best } \\
\text { First Search } \\
\text { menggunakan } \\
\text { Visual Basic } \\
6.0\end{array}$ & $\begin{array}{l}\text { Dilakukan } \\
\text { dengan cara } \\
\text { penerapan } \\
\text { dengan } \\
\text { pedoman yang } \\
\text { ada. }\end{array}$ & $\begin{array}{l}\text { Dilakukan dengan } \\
\text { cara menjalankan } \\
\text { aplikasi pencarian } \\
\text { rute jalur } \\
\text { terpendek dengan } \\
\text { menggunakan } \\
\text { metode Best First } \\
\text { Search. }\end{array}$ \\
\hline $\begin{array}{l}\text { Manfaat } \\
\text { Teknologi }\end{array}$ & Tidak Ada & $\begin{array}{l}\text { Menggunakan } \\
\text { Komputer }\end{array}$ \\
\hline
\end{tabular}

Data Hasil Pengujian Sistem Aplikasi Pencarian Rute Jalur Terpendek Dengan Menggunakan Metode Best First Search Di Perusahaan Roti Surya, Jumlah Responden 7 Orang Yang Merupakan Pimpinan dan Karyawan Roti Surya.

Tabel 4. Jawaban Responden terhadap Sistem baru

\begin{tabular}{|c|l|c|c|c|}
\hline \multirow{2}{*}{ No } & \multicolumn{1}{|c|}{ Pertanyaan } & \multicolumn{3}{|c|}{$\begin{array}{c}\text { Jawaban Responden } \\
\text { (orang) }\end{array}$} \\
\cline { 3 - 5 } & Baik & Cukup & $\begin{array}{c}\text { Kurang } \\
\text { Baik }\end{array}$ \\
\hline 1 & Tampilan Login & 5 & 2 & 0 \\
\hline 2 & Tampilan Menu & 5 & 2 & 0 \\
\hline 3 & $\begin{array}{l}\text { Pertanyaan } \\
\text { Pencarian Rute }\end{array}$ & 7 & 0 & 0 \\
\hline 4 & $\begin{array}{l}\text { Hasil Pencarian } \\
\text { Rute }\end{array}$ & 4 & 3 & 0 \\
\hline 5 & Tampilan Penutup & 7 & 0 & 0 \\
\hline
\end{tabular}

Grafik Data Hasil Pengujian Pembuatan Aplikasi Pencarian Rute Jalur Terpendek Pada Bagian Pemasaran Di Roti Surya Dengan Menggunakan Metode Best First Search.

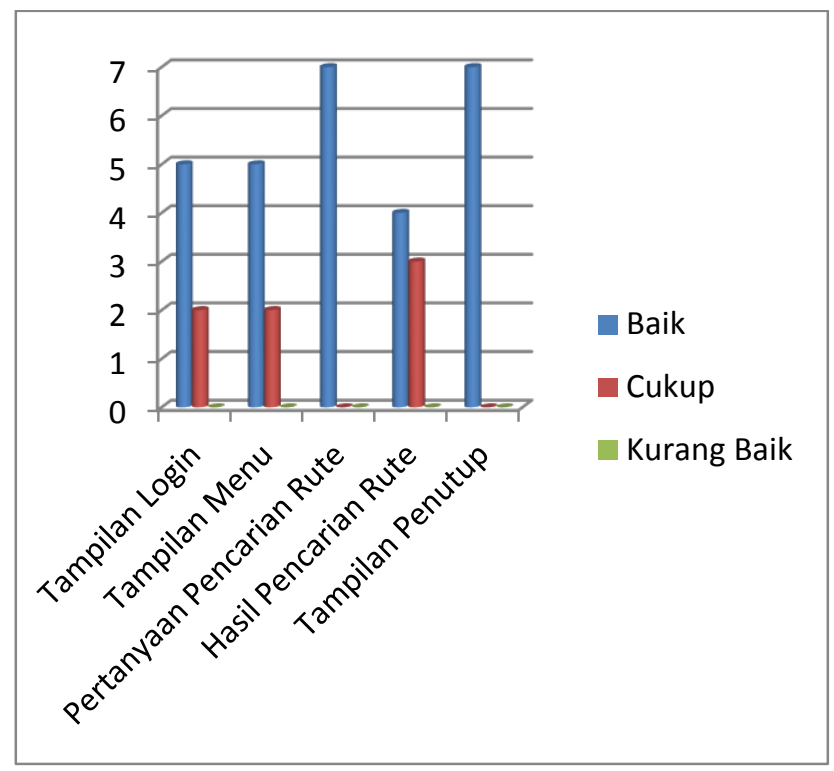

Gambar 25. Grafik Hasil Pengujian

\section{PENUTUP}

\section{A) Kesimpulan}

Hasil uji coba program yang telah dilakukan pada Perusahaan Roti Surya dalam penggunaan program aplikasi yang telah dibuat ini, menunjukkan respon yang baik dari pihak Manajemen Roti Surya. Hal itu terlihat dari beberapa pernyataan yang telah disampaikan pada saat uji coba program untuk mencari rute terpendek.

Selain itu kecepatan dan ketepatan dalam melakukan proses perhitungan jarak dan jangkauan dapat memberikan kemudahan untuk mendistribusikan produk, maka program aplikasi ini layak untuk dimanfaatkan oleh Pabrik Roti Surya meskipun masih memerlukan beberapa perbaikan. Karena sudah sewajarnya perubahan yang terjadi dari cara manual kemudian bergeser ke arah pemanfaatan program komputer.

\section{B) Saran}

Berdasarkan pembahasan dan kesimpulan yang telah diuraikan di atas, saran dan rekomendasi yang dapat penulis berikan adalah:

Perlunya peningkatan kemampuan pengoperasian program, agar keberadaan program sebagai pengganti cara manual menjadi lebih berarti, Memerlukan beberapa perbaikan. 
DAFTAR PUSTAKA

Anonim, 2013. Pengertian Aplikasi. http://id.wikipedia.org/wiki/Aplikasi Diunduh pada tanggal 5 Januari 2015

Firdaus, 2006. Visual Basic 6.0 Untuk Orang Awam. Penerbit. Maxikom. Palembang.

Fredi, S.P. dan Anggraini Mulwinda, 2010. Studi Komparatif Penentuan Rute Jalur Terpendek. Jurnal Kompetensi Teknik. Vol. 2. No. 1. November 2010.

Iing Mutakhiroh, dkk., 2007. Pemanfaatan Metode Heuristik Dalam Pencarian Jalur Terpendek Dengan Algoritma Semut dan Algoritma Genetika. Makalah Seminar Nasional Aplikasi Teknologi Informasi. Yogyakarta, 16 Juni 2007.

Mudi Arsa, 2010. Lintasan Terpendek. http://mudiarsa.blogspot.com/2010/08/ lintasanterpendek.html Diunduh pada tanggal : 5 Januari 2015

Mulyono, H., 2008. Buku Pintar Komputer, Jakarta, Kriya Pustaka.

Novia, A., 2007. Aplikasi Windows dengan Visual Basic Enterprise. Penerbit. PT. Elekmedia Komputindo. Jakarta.

Rusmawan, U., 2004. Mengolah Database dengan SQL dan Crystal Report dalam Visual Basic 6.0. Penerbit : PT. Elex Media Komputindo. Jakarta.

Rusmawan, U., 2009. Koleksi Program VB 6.0 Konsep ADO. Penerbit: PT. Elex Media Komputindo. Jakarta. 